\title{
A Comparative Study of KWL and TWA Techniques upon Students' Reading Competency at SMAN 1 Singaraja
}

\author{
Ekayani, Ni Wayan \\ English Education Department, Ganesha University of Education \\ ekayani45@gmail.com
}

\begin{abstract}
This research aimed at testing which technique between KWL and TWA techniques is better to be used in order to help students in promoting their reading competency to achieve the performance indicator which is set to the tenth-grade students at SMAN 1 Singaraja. The design of the study was Post-test Only Two Non-Control Group Design. The population was 11 classes with 317 tenth-grade students at SMAN 1 Singaraja in which 2 classes were selected as the sample of the research which was determined by using cluster random sampling. One class with 28 students read texts using KWL and the other class with 30 students read texts using TWA technique. The instruments which were used such as lesson plans, try out test and final test. The data were collected through reading test (final test) that were analysed descriptively and inferentially which used one-way ANOVA in inferential statistics analysis. The result shows that, $\mathrm{F}=1.863$ with the significance value was 0.140 which was higher than the significance value of alpha, 0.05. Thus, there is no significant difference on the students' reading competency when they read texts using KWL and TWA technique. Because there is no different on the students' reading competency between the two groups when they read texts using KWL and TWA techniques, Turkey analysis did not need to be administrated.
\end{abstract}

Keywords: KWL technique, reading competency, TWA technique

\section{Introduction}

Reading is a process of conscious and unconscious thinking. The reader applies many strategies to understand the meaning of a text by comparing information in the text to his or her background knowledge and prior experience (Mikulecky, 2008). It becomes a crucial activity since people need to update and improve their knowledge and information. It facilitates people to get new knowledge, entertain, facts, job and source of study materials from various kinds of text.

In relation with learning English, reading is one of the four important skills that language learners need to acquire in order to master English well. Mikulecky and Jeffries (Aprilia, 2015) state that reading is an effective way to improve students' English general language skills. It enlarges English vocabulary, improves writing and speaking skills and find out new information and experiences from a written language.

Comprehending a text is not easy for students although teacher has applied some strategies in teaching reading skill. Most of the Indonesian students are still difficult to comprehend and understand the content of a written text. The fact shows that surveys which was conducted by Program for International Student Assessment (PISA) in 2014 shows Indonesia was in the second position from bottom from 65 participated countries (Gurria, 2014) and the next year later in 2015 in the same survey, Indonesia's position becomes the ninth bottom position from 72 participated countries (Gurria, 2016). This result shows that reading in Indonesia is still problem ahead.

This is due to the fact that students are still hard to comprehend reading text due their difficulty in vocabulary, meaning, and text understanding. Jaya, 2014 states that reading difficulty occurs frequently even in students who are good in decoding and spelling. This difficulty in reading comprehension occurs for many reasons, the four most important ones 
are vocabulary, work memorization, absence of extensive reading and text type (Shehu, 2015). In reading class activity, most of the students answer that they read the text just because they have to, not because they are interested in the text (Utami, 2017).

In order to achieve good achievement, the students should get score which is above the performance indicator. When the students could get score in the test above the performance indicator, they are success in their learning, but when they do not achieve it, they are still in problem. Furthermore, since the research was conducted at SMAN 1 Singaraja, the researcher observed and interviewed the tenth-grade students' English teacher. It is found that the students are still difficult in comprehending text and vocabulary. It is also supported by the result of their English test was still below from the performance indicator (KKM) which was set.

Considering this, applying effective learning strategy should be done by teacher to help the students to involve in learning activities. There are reading intervention techniques which can be applied by teacher to help the students to involve in learning activities. Among those techniques, KWL (Know, Want to know, Learn) and TWA (Think before reading, While reading, After reading) techniques can be applied in teaching reading. KWL is a useful technique in teaching reading developed by Ogle (1986). It provides a way for activating and building prior knowledge, establishing a purpose for reading and summarising what was learned. KWL technique consists of three-step procedure which includes assessing what I Know, determining what I Want to learn and recalling what I did Learned as result of reading activity.

Empirically, some researches have been conducted to investigate the effectiveness of KWL technique toward students' reading comprehension. Some of them are research that was conducted by Yuniarti (2013) proved that teaching reading to students by using KWL technique is effective to improve students' reading comprehension at eleventh grade students of SMA Negeri 1 Sanden. Additionally, the same result is shown in junior high school which was conducted by Karang on her research (2014). It shows students' reading comprehension at eighth grade students of SMP Negeri 1 Amlapura increases when they are taught by using KWL technique.

Furthermore, TWA (Think before reading, think While reading and think After reading) technique is an instructional technique developed by Mason (2004). It is used to improve reading comprehension through self-regulation before, during, and after reading. This technique encourages students to think about their reading task at three points: before reading (about the author's purpose, what the student wants to know and learn), during reading (about reading speed, linking knowledge, and rereading parts), and after reading (about the main idea, summarizing information, and what the student has learned).

Some studies showed that TWA is an effective teaching technique. One of them is research that was conducted by Merson (2016) who investigated ninth- and tenth-grade students to their reading comprehension. The result of the study proved that this technique helps in increasing students' reading comprehension level. The other research conducted by Mason (2013) showed experts have extended 1 such approach, self-regulated strategy development (SRSD) for the expository reading comprehension Think before reading, think While reading, think After reading (TWA) strategy, by integrating instruction for writing, language development, and prompted discourse into the instructional framework. Researchers have found positive performance effects following SRSD for TWA instruction across reading comprehension and language measures, oral and written summarization, oral and written retelling, and informative essay writing. 
Based on the explanation above, it can be concluded that KWL and TWA techniques are effective techniques in increasing students' reading competency. However, the effect of both techniques on students' reading competency have not been known yet. Thus, the researcher is interested in conducting the research to find out which technique is better in promoting students' reading competency.

Regarding to the techniques are used in teaching reading, based on the syllabus and standard competency of reading of tenth grade students in SMAN 1 Singaraja which uses Curriculum 2013, there are two kinds of texts that they are going be leant, descriptive and narrative text. Thus, this study focuses on testing the significant difference on students' reading competency when they read texts by using KWL and TWA techniques and the significant difference on students' reading competency when they read two kinds of text (descriptive and narrative text) using KWL and TWA techniques.

\section{Methods}

This was a comparative experimental research which aimed in testing which technique between KWL and TWA techniques is better to be used in order to help students in promoting their reading competency to achieve the performance indicator which is set to the tenth-grade students at SMAN 1 Singaraja in academic year 2017/2018 which used Posttest Only Two Non-Control Group Design as the design of the study.

The target population was 317 the tenth-grade students in which they were separated in 11 classes. The sample of the study was selected by using cluster random sampling where the researcher selected two classes first. Furthermore, the researcher decided which class would be taught by using KWL and TWA technique. Before giving treatments, the normality and homogeneity of the samples were tested first.

There were two variables on this current study, independent and dependent variables. The dependent variable was students' reading competency and the independent variables were KWL and TWA techniques. Research instruments that were used such as the first one was final test as instrument for collecting data with 30 questions in form of multiple choice with descriptive and narrative text as the material. The second one was teacher scenarios or lesson plans were used as instrument for supportive data in which they were used by the researcher as guidance in giving the treatment when teaching the students. The selected materials were based on the syllabus which were used in SMAN 1 Singaraja. And the last instrument was try out test consisting 50 multiple choice questions with 2 materials that were descriptive and narrative text.

All of the instruments were tested first. Teaching scenarios were consulted to the supervisors first before they were implemented. Before administrating try out test to the class which was not belonging to sample, it was checked first for the content validity by two experts to examine the items appropriately with the indicators. The result analyzed using Gregory formula to obtain the content validity. The result of Gregory's formula was found that the content validity of test was 1.00 which means the content validity was in very high level. It can be inferred that the instrument was valid in term of content. After measuring the content validity, the instrument was tried out the test in class X MIA5. The result of try out test were analyzed by using ANATES program to find out analyzed to find out empirical validity, reliability, index of discrimination and the effectiveness of distracter. In the empirical validity, among 50 items, there were 30 valid items and would be used as the final test to collect the data. The result of reliability test was 0.722 which was categorized as having high level of reliability. 
Then in teaching process of giving treatment for both groups, there were 5 meetings for each group, consists of 2 meetings for preparation then 2 meetings for giving treatment, 1 last meeting for conducting the final test. After conducting final test, the researcher analyzed the data. The data was collected in the form of score of students' reading competency test. The gained scores were calculated and analyzed by using two forms of statistical analysis, namely descriptive and inferential statistical analysis which used SPSS program in analyzing the data. Descriptive statistical analysis analyzed mean, standard deviation and variance of the data. Inferential statistical analysis was used to test the normality and homogeneity of the data. Furthermore, one-way ANOVA test was used in hypothesis testing. The qualifications in determining the result of the hypothesis testing are when the significance value of the test is below significance value of alpha, 0.05 , the null hypothesis was rejected which means there is significant difference on students' reading competency when they read texts using KWL and TWA techniques. In the other hand, when the significance value of the test is above significance value of alpha, 0.05 , the null hypothesis was accepted which means there is no significant difference on students' reading competency when they read texts using KWL and TWA techniques. Furthermore, Tukey analysis would be done when there is significant between the two groups to find out the significant different on the students' reading competency when they read two kinds of texts (descriptive and narrative texts) using KWL and TWA techniques.

\section{Findings}

\section{Finding and Discussion}

Descriptive statistics analysis measures the mean, standard deviation and variance of the students' final test score of the both groups. The result of descriptive statistical analysis could be seen in table 1 .

\begin{tabular}{|c|c|c|c|}
\hline \multirow[t]{2}{*}{ No } & \multirow[t]{2}{*}{ Statistic } & \multicolumn{2}{|l|}{ Group } \\
\hline & & TWA & KWL \\
\hline 1 & Valid & 30 & 28 \\
\hline 2 & Missing & 0 & 0 \\
\hline 3 & Mean & 73 & 75 \\
\hline 4 & Standard Deviation & 5.537 & 4.811 \\
\hline 5 & Variance & 30.668 & 23.148 \\
\hline 6 & Minimum & 65 & 65 \\
\hline 7 & Maximum & 85 & 82.5 \\
\hline 8 & Sum & 2197.5 & 2100 \\
\hline
\end{tabular}

From the table 1, KWL group achieved 2 more point than TWA group based on the mean score. The mean score of TWA group is 73 and the mean score for KWL group is 75 . Furthermore, is 30.668 variance for TWA group with 5.537in standard deviation. KWL group gets 23.148 in variance and 4.811 in standard deviation. Moreover, the minimum and maximum score in TWA group is 65 and 85 with 2197.5 total score. KWL group gets the same minimum score with TWA group but different in maximum score that is 82.5 with 2100 total score.

Furthermore, hypothesis testing was done in order to test whether or not there is any significant difference in reading competency between the tenth-grade students when they read 
texts and whether or not there is any significant difference in reading competency between the tenth-grade students when they read two different texts (descriptive and narrative text) at SMAN 1 Singaraja. Since the data was normal distributed and homogeneous, hypothesis testing could be done. It was analysed by using one-way ANOVA test with SPSS 16.0 program. The result of the testing was displayed in the following table.

Table 2 Result of one-way ANOVA

\begin{tabular}{llccc}
\hline & Sum of Squares & df & Mean Square & ig. \\
\hline Between Groups & 236.743 & 3 & 78.914 & .863 \\
Within Groups & 4743.214 & & & 140 \\
Total & 4979.957 & 112 & 42.350 & \\
\hline
\end{tabular}

Based on the table 2, value of $\mathrm{F}$ is 1.863 with the significance value is 0.140 . The significance value of the data based on the hypothesis testing is higher than significance value of alpha (0.05). Thus, it can be inferred that there is no different on students' reading competency when they read texts using KWL and TWA technique. Since there is no significant difference on the students' reading competency when they read texts using KWL and TWA technique, Tukey test do not need to be administrated. It can be inferred that there is no different on the tenth-grade students' reading competency when they read two kinds of text (descriptive and narrative text) using KWL and TWA technique. Both null hypothesizes are accepted.

\section{Discussion}

This was a comparative experimental research which aimed in testing which technique between KWL and TWA techniques is better to be used in order to help students in promoting their reading competency to achieve the performance indicator which is set to the tenth-grade students at SMAN 1 Singaraja in academic year 2017/2018.

In teaching process of giving treatment for both groups, there were 5 meetings for each group, consists of 2 meetings for preparation then 2 meetings for elaboration, 1 last meeting for conducting the final test. The preparation meetings were conducted to train students first of how those two techniques could help them in reading before they implemented the techniques by themselves. Here, the researcher's role as teacher where the researcher taught the students of applying the techniques. The material for first and second meeting was descriptive text about historical place and tourism object around the world. Then the material of the following meetings was narrative text about legend in Indonesia. There was one text for each material for both techniques, 1 descriptive text and 1 narrative text.

The result of students' score in the final test showed that the students who read texts by using KWL technique got higher score with 2 points than students who read texts by using TWA technique. It proved by the mean score of KWL group was 75 and 73 for TWA group. Descriptively, the students who read texts using KWL technique get higher mean score than the students who read texts using TWA technique. Additionally, from 30 students who read texts using KWL technique, there are 4 students who already reach performance indicator $(\mathrm{KKM}=81)$ and the rest of them still get score which is below performance indicator for both descriptive and narrative texts tests. While, for students who read texts using TWA technique, among 28 number of students, 5 students already reach performance indicator. 
Based on the analysing of one-way ANOVA test, $\mathrm{F}=1.863$ with significance value of the data is 0.140 in which it was higher than significance value alpha $=0.05$. The findings show that there is no significant difference in reading competency between the tenth-grade students when they read texts using KWL and TWA at SMAN 1 Singaraja in academic year $2017 / 2018$.

Based on the observation while teaching KWL technique, the students were taught by using an innovative teaching technique in which the teacher can manage and control the students when studying. KWL technique also allowed students to study in an interesting way of teaching activities since it creates and exists good studying atmosphere which could promote students' reading competency. The interaction among students in the group when sharing idea and doing discussion related to the material build a good atmosphere. Furthermore, when they do learning activities in the group, the students seemed to be more active and interested in the lesson and the passive students can show their self-confidence step by step. This is supported by Dieu in her research in 2015 which proves KWL also suggested a way to control a reading class, to create an interesting and exciting atmosphere to improve students' reading comprehension skill.

In using KWL technique, students are guided by three stages which could promote their reading competency. As Ros \& Vaughn (2002:179) stated it consists of three basic stages. In Know stage, What I Know the students activate their prior knowledge and what they understand about the material to make a list of information. Then in the W stage What I Want to know, students determine what they want to know by making questions related to the material. In Learned stage, What I Learned the students get new information that they have learned and also answer the students' questions; they confirm and recall what they have learned. KWL technique will be useful for both students to evaluate and reflect their learning and teachers which can be used for assessment tool. Empirical reviews stated by Stahl (2008) adds that KWL technique is an instructional technique which can be used to promote students reading comprehension. Yuniarti (2013) proved students' reading comprehension increases when they were taught by using KWL technique. Moreover, Utami, et al., (2015) also proved there was a significant effect of using KWL Strategy on the eleventh-grade students' reading comprehension achievement as well as Riswanto, et al., (2014) on their research showed KWL strategy was effective in improving the students' reading comprehension achievement in learning English as a Foreign Language.

When applying KWL technique, the students are guided by KWL chart. This chart will be useful for students in helping students become active thinkers while reading, help students look for specific things while reading and set as reflection on what they have learned. Other benefits that students can get is it can be used as a short introduction to a lesson to stimulate prior knowledge and assist the teacher's instruction during the teaching and learning process (Ros \& Vaughn, 2002:179).

Furthermore, when the students were taught by using TWA technique, the students provided three main points, before reading, while reading and after reading. The teacher asked the students to think about the author's purpose of the text, what they know about the text then they share what they think to other students. Then while reading the text, the students should check their reading speed, try to link their prior knowledge with the new information in the text and give mark in the part that they want to reread. The students should find out the main idea of each paragraph and make summary then the students think about what they learned from the text as Mason, et al., (2006) state that TWA technique encourages students to think about their reading task at three points: before reading (about the author's purpose, what the student wants to know and learn), during reading (about reading speed, linking 
knowledge, and rereading parts), and after reading (about the main idea, summarizing information, and what the student has learned). It is also proved from the previous research conducted by Merson (2016) that this technique helps in increasing students' reading comprehension level.

In learning process, most of the students' activities were done in the group. By grouping students in doing task, they can share their idea in discussing issue. Furthermore, for the passive students, it is good for them to promote their confidence since they talk to with their friends in the group who they already know without feeling afraid if doing mistake.

The students' mean score in the final test could be similar it might be the first step in each technique is similar. In TWA technique, the students are asked to find out the purpose of the author, then think what they already understand about the material in the text then think what they want to learn and in KWL technique, they students only focuses on what they know about the material by looking the tittle of the text, looking the related picture, etc. but the main focus in KWL technique is in activating students prior knowledge which is done in the first stage while the focus in TWA is in linking students' prior knowledge with the new information that they get while reading the text. It is supported by the second step in TWA which contains reread point there in which when students do not understand yet the part of the text when they read once, the step provides students to read again in order to understand the text. The difference between KWL and TWA technique also at the last step which in KWL technique, the students only recall and answer the information that they get but in TWA technique, the students are asked to find out the main idea of the paragraph then make summary of it.

Based on the theories and previous researches about the techniques, those stated that KWL and TWA techniques are effective reading techniques which could help students in promoting their reading competency. It was proved by there is improvement on the students' score before and after treatment. But since more than a half student do not reach the performance indicator which is set, the techniques are not effective to be used in this case. Based on the analysis which was done by looking students' work when they applying the technique in reading texts, in KWL group, the students still have problem in list what information that they want to know which is done in the second stage especially when they read narrative text. They look confuse in listing the information that they want to know because the students do not the chronological events exactly. Furthermore, in TWA group, the students are still difficult in find out the main idea of each paragraph and make summarization when they read narrative text which are done in the last stage. Since narrative text is a past story which is told chronologically, few students forget in using Verb 2 in writing summary.

Furthermore, because there is no significant difference on the students' reading competency when they read texts using KWL and TWA technique, Tukey test which is aimed to test the different between the two group when they read two kinds of text (descriptive and narrative text) do not need to be administrated. It can be concluded that, there is no different in student's reading competency when they read two kinds of texts, descriptive and narrative text.

\section{Conclusion}

Descriptively, the students who read texts using KWL technique get higher mean score than the students who read texts using TWA technique. Additionally, from 30 students who read texts using KWL technique, there are 4 students who already reach performance indicator $(\mathrm{KKM}=81)$ and the rest of them still get score which is below performance indicator for both descriptive and narrative texts tests. While, for students who read texts using TWA 
technique, among 28 number of students, 5 students already reach performance indicator. Inferentially, The findings and discussion showed that there is no significant difference in students' reading competency when they read texts using KWL and TWA technique and there is no significant difference in reading competency between the tenth-grade students when they read two different texts (descriptive and narrative text) at SMAN 1 Singaraja in academic year 2017/2018. This is supported by the result of descriptive statistics analysis and the inferential statistics analysis. The students enjoy learn in the classroom and look enthusiasm. It is also because they already know the texts; descriptive and narrative text are not new text for them since they have known these text in junior high school.

\section{References}

Aprilia, N. 2015. Improving reading comprehension of the eighth-grade students at SMPN 6 Yogyakarta through POSSE strategy in the academic year of 2014/2015. (Undergraduate's thesis, State University of Yogyakarta, Yogyakarta, Indonesia).

Asgarabadi, Y. H., Rouhi, A., Jafarigohar, M., 2015. Learners' Gender, Reading Comprehension, and Reading Strategies in Descriptive and Narrative Macro-genres. Journal of Theory and Practice in Language Studies. 5(12), 2557-2564. doi: http://dx.doi.org/10.17507/tpls.0512.17.

Connors, L. T. 2014. Definitions and approaches to measuring reading proficiency.

Dieu, T., T., T. 2015. Trying K-W-L strategy on teaching reading comprehension to passive students in Vietnam. International Journal of Language and Linguistics. 3(6), 481492. doi: 10.11648/j.ij11.20150306.33.

Fengjuan, Z. (2010). The Integration of the Know-Want-Learn (KWL) Strategy into English Language Teaching for Non-English Majors. Chinese: Chinese Journal of Applied Linguistics (Bimonthly). Soochow University.

Gurria, A. 2014. PISA 2012 Results in Focus, What 15-Year-Olds Know and What They Can Do With What They Know.

Gurria, A. 2016. PISA 2015 Results in Focus.

Hamdan, M., H. 2014. Theory and practice in language studies. KWL-Plus Effectiveness on Improving Reading Comprehension of Tenth Graders of Jordanian Male Students. 4(11), 2278-2288.

Irwin, J.,W. 2007. Teaching reading comprehension process (3rd ed.). Pearson Education, Inc.

Jaya, C. 2014. Performance assessment in teaching EFL reading in Indonesia: viewed from first language (li) use to check Learners' comprehension. Paper presented at The Second International Conference on Education and Language (2nd ICEL) Bandar Lampung University (UBL), Indonesia.

Karang, A.A. A. D. P. 2014. Improving reading comprehension through KWL strategy at the eighth-grade students of SMPN 1 Amlapura in academic year 2013/2014. (Undergraduate's thesis, Mahasaraswati Denpasar University, Denpasar, Bali, Indonesia).

Klingner, J. K., Orrison, A.M, Eppolito, A. 2011. Handbook of Reading Interventions. The Guilford Press.

Mason, L.H. 2013. Teaching Students Who Struggle with Learning Think Before, While and After Reading: The Effect of Self-Regulated Strategy Development Instruction. 29(6), 124-144.

Mikulecky, B. S. 2008. Teaching reading in a second language. 
Merson, J. 2016. The effect of the TWA reading Strategy on the reading comprehension level of 9th - and 10th-grade students. (Graduate's thesis, Goucher College).

Ogle, D. M. 1986. K-W-L: A teaching model that develops active reading of expository text. Journal of International Reading Association.39(6), 564-570.

Pang, E.S., Muaka, A., Bernhardt, E.B., \& Kamil, M.L. 2003. Teaching reading. Brussels: International Academy of Education (IAE).

Riswanto, Risnawati, \& Lismayanti, D. 2014. The effect of using KWL (Know, Want, Learned) strategy on EFL students' reading comprehension achievement. International Journal of Humanities and Social Science. 4(7), 225-233.

Ros, C. and Vaughn, S. 2002. Strategies for teaching students with learning and behavior problems. USA: Rinehart and Winston, Inc.

Shehu, I. 2015. Reading Comprehension Problems Encountered by Foreign Language Students, Case Study: Albania, Croatia. Academic Journal of Interdisciplinary Studies MCSER Publishing, Rome-Italy. 4(1). doi: 10.5901/ajis.2015.v4n1s1p91

Stahl, K., A,. D. 2008. The effects of three instructional methods on the reading comprehensionand content acquisition of novice readers. Journal of Literacy Research. 40, 359-393.

Sugiarta, I.K. 2013. A Comparative Study on the Effect of TWA and QAR Technique upon Reading Comprehension on the Seventh Grade Students of SMPN 2 Banjar in the Academic Year 2012/2013. (Undergraduate's thesis, Ganesha University of Education, Bali, Indonesia).

Utami, D., K., E., Bindarti, W., K., \& Suharjito, B. 2015. The effect of using KWL (knowwant to know-learned) strategy on the eleventh-grade students' reading comprehension achievement at SMAN 1 Besuki in the 2014/2015 academic year.

Utami, I., A., M., I. 2017. The study of potentials and problems in reading faced by the eighth-grade students of junior high school. Journal of Education Research and Evaluation. 1(1) pp. 23-29.

Yuniarti, E. 2013. Improving the students' reading comprehension through Know-WantLearn technique at the eleventh grade of SMA Negeri 1 Sanden in the academic year of 2012/2013. (Undergraduate's thesis, State University of Yogyakarta, Yogyakarta, Indonesia). 